\title{
21. TRACE-ELEMENT GEOCHEMISTRY OF THOLEIITIC BASALTS FROM SITE 433C, SUIKO SEAMOUNT
}

\author{
David A. Clague, Department of Geology, Middlebury College, Middlebury, Vt. \\ and \\ Fred A. Frey, Department of Earth and Planetary Sciences, Massachusetts Institute of Technology, \\ Cambridge, Ma. 02139
}

\section{INTRODUCTION}

Hole $433 \mathrm{C}$, a multiple re-entry hole drilled in 1862 meters of water on Suiko Seamount in the central Emperor Seamounts, penetrated 387.5 meters of lava flows overlain by 163.0 meters of sediments. The recovered volcanic rocks consist of three flow units (1-3) of alkalic basalt underlain by more than 105 flows or flow lobes (Flow Units 4-67) of tholeiitic basalt. The stratigraphy of the site and locations of the samples studied are shown in Figure 1.

This study reports trace-element, including rare-earth element (REE), data for 25 samples from 24 of the least altered tholeiitic flows. These data are used to evaluate the origin and evolution of tholeiitic basalts from Suiko Seamount and to evaluate changes in the mantle source between the time when Suiko Seamount formed, $64.7 \pm$ $1.1 \mathrm{~m} . y$. ago (see Dalrymple et al., this volume), and the present day.

Stearns (1946), Macdonald and Katsura (1964) and Macdonald (1968) have established that chemically distinct lavas erupt during four eruptive stages of development of a Hawaiian volcano. These stages, from initial to final, are shield-building, caldera-filling, post-caldera, and post-erosional. The lavas of the shield-building stage are tholeiitic basalts, which erupt rapidly and in great volume. The shield-building stage is quickly followed by caldera collapse and by the caldera-filling stage, during which the caldera is filled by tholeiitic and alkalic lavas. During the post-caldera stage, a relatively thin veneer of alkalic basalts and associated differentiated lavas are erupted, sometimes accompanied by minor eruptions of tholeiitic lava. After a period of volcanic quiescence and erosion, lavas of the nephelinitic suite, which include both alkalic basalts and strongly $\mathrm{SiO}_{2}$-undersaturated nephelinitic basalts, may erupt from satellite vents during the post-erosional stage. Many Hawaiian volcanoes develop through all four stages; but individual volcanoes have become extinct before the cycle is complete.

We interpret the tholeiitic lavas drilled on Suiko Seamount to have erupted during either the shield-building or the caldera-filling stage, and the overlying alkalic flows to have erupted during either the caldera-filling or the post-caldera stage (see Kirkpatrick et al., this volume).

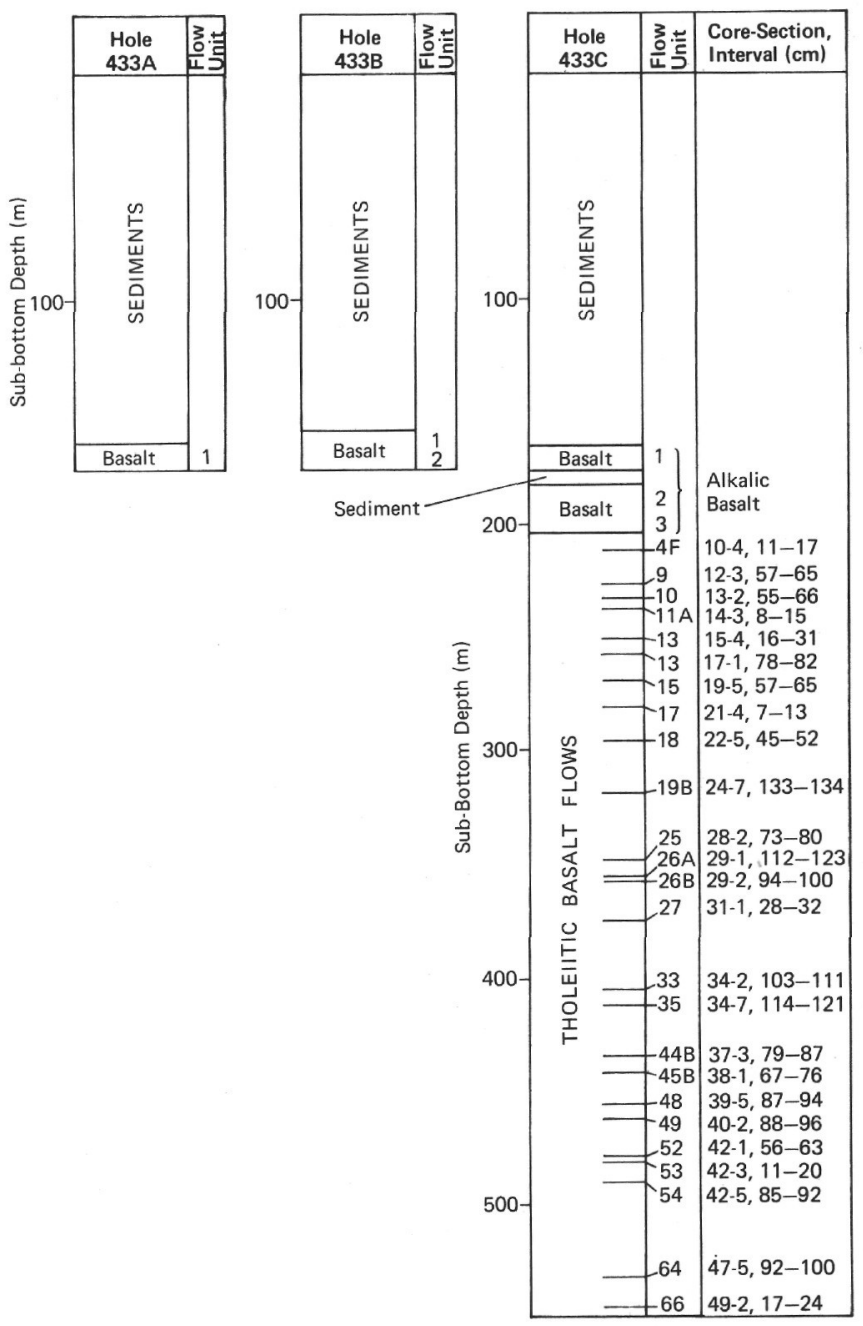

Figure 1. Stratigraphic column for Holes 433A, 433B, and $433 C$ on Suiko Seamount, showing the flow units and locations of the analyzed samples. Depth is in meters below the mudline.

\section{SAMPLES STUDIED}

The samples selected for trace-element study were also used for analyses for major-element compositions (Kirkpatrick et al., this volume), mineralogic studies (Clague et al., this volume), and $\mathrm{Sr}$-isotopic analyses 
(Lanphere et al., this volume). These samples were selected after examining 204 thin sections and considering the shipboard chemical analyses (see Site 433 chapter). In general, the analyzed samples are the least altered, although we tried to ensure a representative stratigraphic sampling. The petrography of the samples is summarized in Table 1. REE were analyzed for a smaller subset of the samples, as indicated in Table 1, and in general, these samples have the lowest total $\mathrm{H}_{2} \mathrm{O}$ concentrations (0.99 to 5.06 wt. \%, Table 1$)$.

Most samples are tholeiitic basalt, and have hypersthene in the CIPW norms calculated with $\mathrm{Fe}^{+3} / \mathrm{Fe}^{\mathrm{T}}=$ 0.15, except Samples 12-3, 57-65 cm and 47-5, 92-100 $\mathrm{cm}$ which are slightly nepheline-normative. Sample

TABLE 1

Petrographic Summary of Hole 433C Tholeiitic Basalts

\begin{tabular}{|c|c|c|c|c|c|c|c|c|c|}
\hline \multirow{2}{*}{$\begin{array}{l}\text { Core-Section, } \\
\text { Interval }(\mathrm{cm})\end{array}$} & \multirow{2}{*}{$\begin{array}{l}\text { Flow } \\
\text { Unit }\end{array}$} & \multicolumn{3}{|c|}{ Phenocrysts (\%) } & \multirow{2}{*}{$\begin{array}{l}\text { Dominant } \\
\text { Texture }\end{array}$} & \multirow[b]{2}{*}{$\mathrm{H}_{2} \mathrm{O}_{\mathrm{T}}$} & \multirow{2}{*}{$\begin{array}{c}\mathrm{Mg} \\
\text { Value }\end{array}$} & \multirow[b]{2}{*}{ REE } & \multirow[b]{2}{*}{ Alteration } \\
\hline & & O1 & Plag & $\mathrm{Cpx}$ & & & & & \\
\hline $10-4,11-17$ & 4 & 5 & 0 & 0 & $\begin{array}{l}\text { Variolitic, } \\
\text { vesicular }\end{array}$ & 9.30 & 65.9 & $\mathrm{~N}$ & $\begin{array}{l}\text { Olivine replaced by clay with iddingsite rims; } \\
\text { vesicles are clay-lined. }\end{array}$ \\
\hline $12-3,57-65$ & 9 & 1 & 3 & 1 & Intergranular & 3.70 & 59.9 & $\mathrm{~N}$ & $\begin{array}{l}\text { Olivine replaced by clay and calcite with iddingsite } \\
\text { rims, vesicles are clay- and calcite-filled. }\end{array}$ \\
\hline $13-2,55-66$ & 10 & 1 & 12 & 4 & Diabasic & 3.70 & 57.4 & $\mathrm{Y}$ & Olivine and intersertal glass replaced by clays. \\
\hline $14-3,8-15$ & $11 \mathrm{~A}$ & 0 & 6 & 1 & $\begin{array}{l}\text { Intergranular, } \\
\text { vesicular }\end{array}$ & 4.85 & 54.0 & Y & $\begin{array}{l}\text { Vesicles are clay-lined, plagioclase cores replaced } \\
\text { by clays. }\end{array}$ \\
\hline $15-6,16-31$ & 13 & $<1$ & 1 & 1 & Intergranular & 2.00 & 52.4 & $\mathrm{~N}$ & Olivine and groundmass glass replaced by clays. \\
\hline $17-1,78-82$ & 13 & $<<1$ & 2 & $<1$ & $\begin{array}{l}\text { Intergranular, } \\
\text { subtrachytic }\end{array}$ & 0.98 & 51.1 & Y & Olivine replaced by clays. \\
\hline $19-5,57-65$ & 15 & 1 & 3 & $<1$ & Intergranular & 3.92 & 58.8 & $\mathrm{Y}$ & $\begin{array}{l}\text { Olivine replaced by clays with iddingsite rims, } \\
\text { plagioclase cores and groundmass glass replaced by } \\
\text { clays. }\end{array}$ \\
\hline $21-4,7-13$ & 17 & $<1$ & 1 & 0 & Intergranular & 4.05 & 57.1 & $\mathrm{~N}$ & $\begin{array}{l}\text { Olivine replaced by iddingsite and clays, plagio- } \\
\text { clase partially, and glass completely replaced by } \\
\text { clays and zeolites. }\end{array}$ \\
\hline $22-5,45-52$ & 18 & 2 & 7 & 0 & Pilotaxitic & 3.18 & 54.1 & $\mathrm{Y}$ & $\begin{array}{l}\text { Olivine replaced by clays and iddingsite, ground- } \\
\text { mass clays after glass. }\end{array}$ \\
\hline 24-7, 133-139 & $19 \mathrm{~B}$ & 39 & 0 & 0 & Diabasic & 5.99 & 79.1 & $\mathrm{~N}$ & $\begin{array}{l}\text { Olivine partly replaced by iddingsite and clays, } \\
\text { plagioclase partly replaced by clays. }\end{array}$ \\
\hline $28-2,73-80$ & 25 & $<<1$ & 5 & 1 & Pilotaxitic & 2.24 & 54.5 & $\mathrm{Y}$ & $\begin{array}{l}\text { Olivine replaced by clays, clay patches in } \\
\text { groundmass. }\end{array}$ \\
\hline $29-1,112-123$ & $26 \mathrm{~A}$ & $<1$ & 5 & 1 & Intergranular & 2.50 & 54.9 & $\mathrm{Y}$ & Olivine and groundmass glass replaced by clays. \\
\hline $29-2,94-100$ & $26 \mathrm{~B}$ & 1 & 7 & $<1$ & Pilotaxitic & 2.25 & 53.1 & $\mathrm{Y}$ & $\begin{array}{l}\text { Olivine, plagioclase cores, and groundmass glass } \\
\text { replaced by clays and zeolites. }\end{array}$ \\
\hline $31-1,28-34$ & 27 & 6 & 7 & 0 & Pilotaxitic & 1.88 & 58.1 & $\mathrm{Y}$ & $\begin{array}{l}\text { Olivine altered to clay along fractures, rare } \\
\text { plagioclase cores replaced by clays. }\end{array}$ \\
\hline $34-2,103-111$ & 33 & 15 & 1 & 0 & Sub-ophitic & 5.11 & 66.2 & $\mathrm{~N}$ & $\begin{array}{l}\text { Olivine replaced by clays with iddingsite rims, rare } \\
\text { groundmass patches of clays. }\end{array}$ \\
\hline $34-7,114-121$ & 35 & 9 & 3 & $<1$ & Pilotaxitic & 4.33 & 65.0 & $\mathrm{Y}$ & $\begin{array}{l}\text { Olivine replaced by clays and calcite with idding- } \\
\text { site rims, irregular clay patches in groundmass. }\end{array}$ \\
\hline $37-3,79-87$ & $44 \mathrm{~B}$ & 2 & 0 & 0 & Diabasic & 3.60 & 61.8 & $\mathrm{~N}$ & $\begin{array}{l}\text { Olivine replaced by clays, some patches of ground- } \\
\text { mass clays. }\end{array}$ \\
\hline $38-1,67-76$ & $45 \mathrm{~B}$ & 9 & 0 & 0 & Sub-ophitic & 4.76 & 67.3 & $\mathrm{~N}$ & $\begin{array}{l}\text { Olivine partially replaced by clays and rimmed by } \\
\text { iddingsite, abundant groundmass clays. }\end{array}$ \\
\hline $39-5,87-94$ & 48 & 5 & $<<1$ & 0 & Intergranular & 2.85 & 65.9 & $\mathrm{Y}$ & $\begin{array}{l}\text { Olivine mostly replaced by clays, some ground- } \\
\text { mass clays. }\end{array}$ \\
\hline $40-2,88-96$ & 49 & 8 & $<<1$ & $<<1$ & Intergranular & 2.73 & 67.1 & $\mathrm{Y}$ & $\begin{array}{l}\text { Olivine partly replaced by clays and rimmed by } \\
\text { iddingsite, some groundmass clays. }\end{array}$ \\
\hline $42-1,56-63$ & 52 & 1 & $<1$ & $<1$ & Intersertal & 3.60 & 57.4 & $\mathrm{Y}$ & Abundant intersertal glass replaced by clays. \\
\hline $42-3,11-20$ & 53 & 1 & 15 & 4 & Intersertal & 4.80 & 60.9 & $\mathrm{Y}$ & Olivine replaced by iddingsite and glass by clays. \\
\hline $42-5,85-92$ & 54 & 1 & 13 & 1 & $\begin{array}{l}\text { Diabasic, } \\
\text { intersertal }\end{array}$ & 2.71 & 57.8 & $\mathrm{Y}$ & Olivine replaced by iddingsite and glass by clays. \\
\hline $47-5,92-100$ & 64 & 2 & 1 & $<<1$ & Pilotaxitic & 4.03 & 44.6 & $\mathrm{Y}$ & $\begin{array}{l}\text { Olivine replaced by iddingsite, plagioclase partially } \\
\text { altered to clays, abundant phillipsite in ground- } \\
\text { mass. }\end{array}$ \\
\hline $49-2,17-24$ & 66 & 1 & 2 & 1 & Diabasic & 5.06 & 49.1 & $\mathrm{Y}$ & Olivine replaced by iddingsite and glass to clays. \\
\hline
\end{tabular}


$12-3,57-65 \mathrm{~cm}$, however, is a tholeiitic basalt: it contains groundmass clinopyroxene with Wo as low as 30 per cent (see Clague et al., this volume). Sample 47-5, 92-100 cm could be a single flow of alkalic or transitional basalt within the tholeiitic sequence of flows. It contains abundant groundmass olivine; but this is also a characteristic of tholeiitic Sample 49-2, 17-42 cm. Sample $47-5,92-100 \mathrm{~cm}\left(\mathrm{~K}_{2} \mathrm{O}=1.51\right.$ wt. $\left.\%\right)$ contains abundant phillipsite, which probably accounts for its apparent alkalic nature.

Many of the tholeiitic flows, including some that were analyzed, are moderately to badly altered. Abundances of mobile cations such as the alkali metals were probably increased by this alteration; e.g., the $\mathrm{K}_{2} \mathrm{O}$ content in several tholeiitic samples is far higher than expected in Hawaiian tholeiites (i.e., $>0.5$ wt. $\% \mathrm{~K}_{2} \mathrm{O}$ ). Furthermore, Samples 21-4, 7-13 cm and 29-2, 94-100 $\mathrm{cm}$, with anomalously high $\mathrm{K}_{2} \mathrm{O}$ contents $(\sim 0.9 \mathrm{wt} . \%)$, contain minor amounts of secondary zeolites and have sanidine replacement of plagioclase cores.

\section{DATA AND ANALYTICAL TECHNIQUES}

All tholeiitic samples analyzed for major elements (Kirkpatrick et al., this volume) were also analyzed by $\mathrm{X}$-ray fluorescence for $\mathrm{Ba}, \mathrm{Cr}, \mathrm{Ni}, \mathrm{Sr}, \mathrm{Zn}$, and $\mathrm{Zr}$, in the U. S. Geological Survey laboratory at Menlo Park (Table 2).

A subset of 17 samples was analyzed by instrumental neutron activation analysis (INAA) for $\mathrm{Sc}, \mathrm{Cr}, \mathrm{Co}, \mathrm{Hf}$, $\mathrm{Ta}, \mathrm{Th}$, and the rare-earth elements $\mathrm{La}, \mathrm{Ce}, \mathrm{Nd}, \mathrm{Sm}$, $\mathrm{Eu}, \mathrm{Tb}, \mathrm{Yb}$, and $\mathrm{Lu}$ at Massachusetts Institute of Technology (Table 3 ). Table 4 compares the $\mathrm{Cr}$ data obtained by XRF with that obtained by INAA. The results are generally acceptable, except where the XRF data approach the detection limit of $100 \mathrm{ppm}$. Accuracy of the INAA data can be evaluated with the BHVO-1 data in Table 3, and precision is indicated by duplicate analyses of the samples from Sections 13-2, 19-5, and 22-4 in Table 3.

\section{DISCUSSION}

\section{Rare Earth Elements}

The chondrite-normalized REE abundances in stratigraphic sequence are plotted against atomic number in Figure 2. All samples have patterns of similar shape, showing relative light-REE enrichment with a distinctive slope that is quite flat from $\mathrm{Eu}$ to La. The parallel character of the patterns suggests that the different absolute REE abundances in the various samples result either from shallow fractionation involving phases such as olivine, which do not fractionate the REE, or from slightly different degrees of partial melting of a homogeneous source.

If these lavas represent residual liquids generated by shallow crystal fractionation from a common parental magma, we would expect to find a strong inverse correlation between $\mathrm{REE}$ abundances and $\mathrm{Mg}$ number or $\mathrm{Ni}$ content (Table 2). A plot of $\mathrm{La}$ against $\mathrm{Mg}$ number (Figure 3) shows considerable scatter, and demonstrates that samples having the same Mg-value differ by a fac- tor of nearly 1.5 in La concentration. This suggests that the lavas are not derived from a single parental magma by shallow fractionation but rather represent differentiates from a range of parental liquid compositions. This conclusion is valid, however, only if the $\mathrm{Mg}$ numbers of the samples have not been changed by alteration and the $\mathrm{Fe}^{3} / \mathrm{Fe}^{\mathrm{T}}$ ratios were similar for each magma. In Figure 3 the samples appear to fall into two main fractionation trends with 30 to 40 per cent differences in $\mathrm{La}$ content for samples with the same $\mathrm{Mg}$ number.

The two lava groups with different La abundances are identical to the two groups defined by differences in $\mathrm{TiO}_{2}$ content (see Kirkpatrick et al, this volume). Samples with relatively high $\mathrm{TiO}_{2}$ contents at a given $\mathrm{Mg}$ number also contain high abundances of $\mathrm{La}$ (see Figure 4). The stratigraphic distribution of the two groups indicates that they are interlayered. Therefore, the parental lava compositons for a single volcano may have alternated from one lava group to the other, or the drill core sampled interfingered flows from two adjacent volcanoes with distinct parental magmas.

In order to evaluate the mantle source compostion of these tholeiites, it is necessary to see through the effects of shallow crystal fractionation and low-temperature alteration. The most direct way to do this is to consider only unaltered samples that have not experienced crystal fractionation. All these tholeiites have been altered; therefore, at best we can only infer the abundances of

TABLE 2

Trace-Element Analyses of Lava Flows from Suiko Seamount, DSDP Hole 433C (Concentrations in ppm)

\begin{tabular}{llrlrrrr}
\hline $\begin{array}{l}\text { Core-Section, } \\
\text { Interval }(\mathrm{cm})\end{array}$ & $\begin{array}{l}\text { Flow } \\
\text { Unit }\end{array}$ & $\mathrm{Ba}$ & $\mathrm{Cr}$ & $\mathrm{Ni}$ & $\mathrm{Sr}$ & $\mathrm{Zn}$ & $\mathrm{Zr}$ \\
\hline $10-4,11-17$ & $4 \mathrm{~F}$ & 174 & $<100$ & 275 & 200 & 121 & 129 \\
$12-3,57-65$ & 9 & 107 & $<100$ & 127 & 305 & 128 & 143 \\
$13-2,55-66$ & 10 & 144 & 224 & 89 & 245 & 85 & 140 \\
$14-3,8-15$ & $11 \mathrm{~B}$ & 87 & 116 & 43 & 285 & 116 & 162 \\
$15-6,16-31$ & 13 & 95 & 110 & 56 & 290 & 117 & 163 \\
$19-5,57-65$ & $15 \mathrm{~A}$ & 178 & 250 & 101 & 275 & 101 & 127 \\
$21-4,7-13$ & 17 & 163 & 172 & 106 & 340 & 150 & 173 \\
$22-5,45-52$ & 18 & 156 & 186 & 99 & 350 & 117 & 173 \\
$24-7,133-139$ & $19 \mathrm{D}$ & 70 & 390 & 860 & 87 & 128 & 79 \\
$29-1,112-123$ & $26 \mathrm{~A}$ & 101 & $<100$ & 70 & 300 & 113 & 169 \\
$29-2,94-100$ & $26 \mathrm{~B}$ & 98 & $<100$ & 61 & 305 & 128 & 194 \\
$34-2,103-1.11$ & 33 & 79 & 470 & 350 & 240 & 99 & 121 \\
$34-7,114-121$ & 35 & 98 & 385 & 260 & 280 & 114 & 151 \\
$37-3,79-87$ & 44 & 66 & 310 & 142 & 96 & $<5$ & 111 \\
$38-1,67-76$ & $45 \mathrm{~B}$ & 94 & 440 & 385 & 260 & 119 & 133 \\
$39-5,87-94$ & 48 & 99 & 410 & 270 & 150 & 114 & 131 \\
$40-2,88-96$ & 49 & 98 & 410 & 310 & 235 & 111 & 137 \\
$42-1,56-63$ & 52 & 85 & 235 & 82 & 260 & 112 & 156 \\
$42-3,11-20$ & 53 & 63 & 255 & 81 & 265 & 87 & 101 \\
$42-5,85-92$ & 54 & 64 & 255 & 76 & 250 & 70 & 129 \\
$47-5,92-100$ & 64 & 118 & 270 & 127 & 270 & 113 & 183 \\
$49-2,17-24$ & 66 & 215 & 113 & 111 & 320 & 123 & 175 \\
\hline
\end{tabular}

Note: The analyses have an average relative error (accuracy) of $2.5,9.0,3.3,4.9,4.0$ and 3.7 per cent for $\mathrm{Ba}, \mathrm{Cr}, \mathrm{Ni}, \mathrm{Sr}, \mathrm{Zn}$, and $\mathrm{Zr}$, respectively. The relative error cited is the deviation of values for standard rocks from a linear working curve after matrix corrections (see discussion in King et al., 1978). 
TABLE 3

INNA Trace-Element Data, Tholeiitic Basalt Flows from Suiko Seamount, DSDP Hole 433C (Concentrations in ppm)

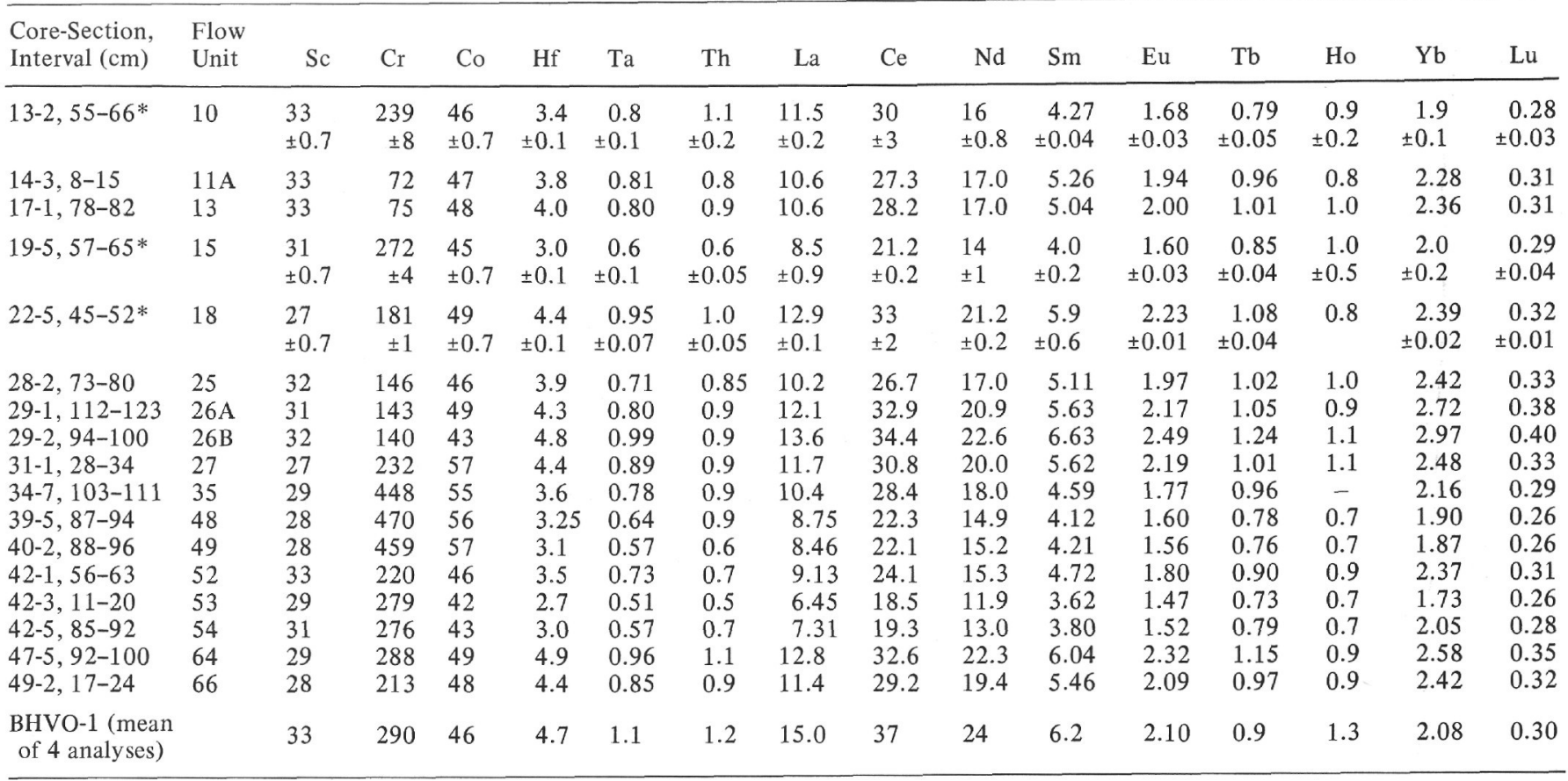

*Duplicate analysis.

TABLE 4

Comparison of $\mathrm{Cr}$ Determined by XRF and by INAA

\begin{tabular}{lcc}
\hline $\begin{array}{l}\text { Core-Section, } \\
\text { Interval }(\mathrm{cm})\end{array}$ & XRF Cr & INAA Cr \\
\hline $13-2,55-66$ & 224 & 234 \\
$14-3,8-15$ & 116 & 72 \\
$19-5,57-65$ & 250 & 270 \\
$22-5,45-52$ & 186 & 181 \\
$29-1,112-123$ & 100 & 143 \\
$29-2,94-100$ & 100 & 140 \\
$34-7,114-121$ & 385 & 448 \\
$39-5,87-94$ & 410 & 470 \\
$40-2,88-96$ & 410 & 459 \\
$42-1,56-63$ & 235 & 220 \\
$42-3,11-20$ & 255 & 279 \\
$42-5,85-92$ & 255 & 276 \\
$47-5,92-100$ & 270 & 288 \\
$49-2,17-24$ & 113 & 213 \\
\hline
\end{tabular}

relatively non-mobile trace elements (e.g., REE) in the mantle source. In addition, most of these tholeiites do not have compositions characteristic of primary magmas derived from a pyrolite mantle (e.g., Frey et al., 1978). ${ }^{1}$ However, 6 samples (Table 2 ) have Ni concen-

1 It has been postulated (e.g., Shaw and Jackson, 1973) that the source materials for Hawaiian tholeiites are more iron-enriched $(\mathrm{Mg}$ number $\sim 82$ ) than pyrolite; however, the similarity between Hawaiian spinel lherzolite inclusions and those from continental localities (Kuno and Aoki, 1970; Reid and Woods, 1978) provide strong evidence that the upper mantle lherzolite source materials are similar beneath Hawaii and continental areas such as the southwest U.S.

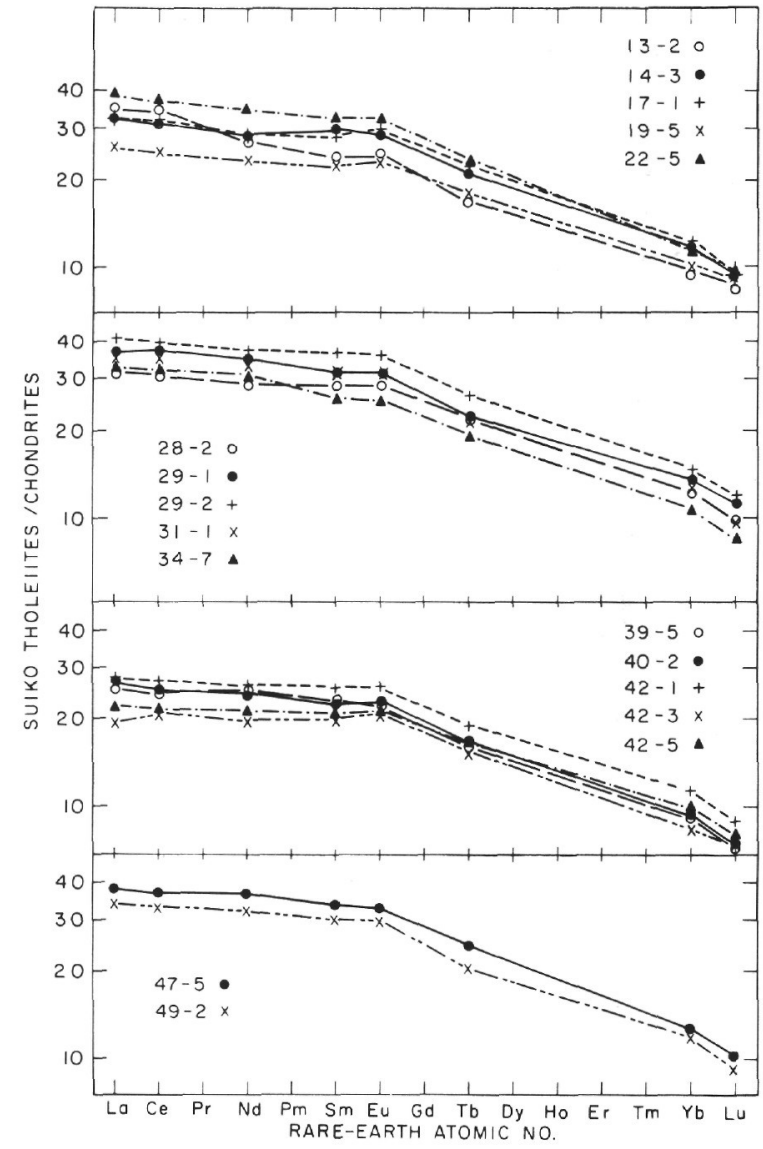

Figure 2. Rare-earth element abundances, normalized to a chrondite average; rocks arranged in stratigraphic sequence. 


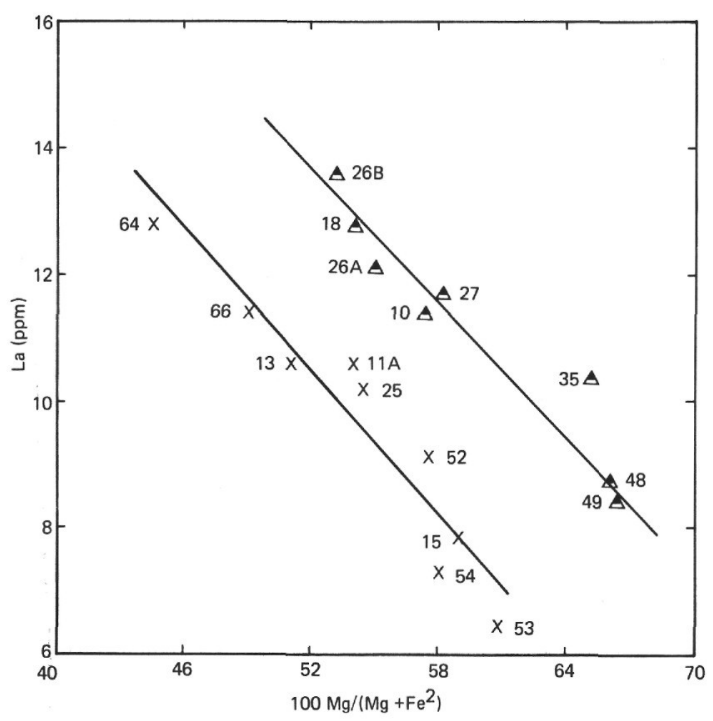

Figure 3. La as a function of $\mathrm{Mg}$ number $[100 \mathrm{Mg} / \mathrm{Mg}$ $\left.\left.+\mathrm{Fe}^{+2}\right)\right]$, calculated with $\mathrm{Fe}^{+3} / \mathrm{Fe}_{T}=0.15$. Note that the samples may be subdivided into two discrete groups with only a few samples of intermediate composition. The individual samples are identified by flow unit (see Figure 1 or Table 1).

trations exceeding $250 \mathrm{ppm}$ and 3 of these (from Sections 34-7, 39-5, 40-2, all members of the high- $\mathrm{TiO}_{2}$ group) have been analyzed for REE. These samples also have the highest $\mathrm{Mg}$ numbers ( $\sim 68$, Table 2$)$ and the lowest $\mathrm{Al}_{2} \mathrm{O}_{3} / \mathrm{CaO}$ ratios (Kirkpatrick et al., this volume), indicating that their compositions are not far removed from a primary magma in equilibrium with a pyrolite composition mantle. As discussed by Leeman et al. (1979), it is likely that Hawaiian tholeiites with similar and slightly lower $\mathrm{Mg}$ numbers are simply related to primary magmas by $<15$ per cent olivine fractionation. Because olivine does not fractionate the relative abundances of incompatible elements, we can infer the relative abundances of immobile incompatible trace elements in the mantle source. Of course, if the mantle source of Hawaiian tholeiites is Fe-rich relative to pyrolite (Shaw and Jackson, 1973), the three high-Ni tholeiites may be very close to a primary magma composition.

The chondrite-normalized REE distributions in the Suiko Seamount tholeiites are similar to those of tholeiites from active Hawaiian volcanoes (Figure 5), although the Suiko samples have even less relative fractionation of the light and middle REE, La to Eu. These REE characteristics, little relative fractionation of light REE compared with extensive relative fractionation of heavy REE, are typical of Hawaiian tholeiites, and they provide important constraints on the composition and mineralogy of the mantle source (Leeman et al., 1977, 1979). Melts with REE abundances similar to the Suiko tholeiites can be generated from a source with relative REE abundances as in chondrites if (1) the extent of melting is large enough and the amount of residual clinopyroxene is small enough so that all of the light REE are partitioned into the melt, and (2) a few per cent gar-

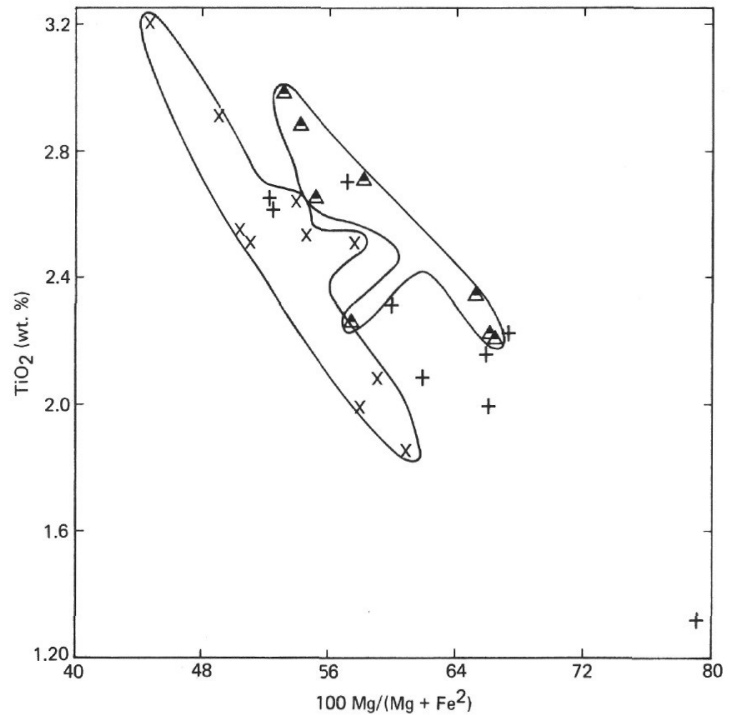

Figure 4. $\mathrm{TiO}_{2}$ as a function of $\mathrm{Mg}$ number [100 $\left.\mathrm{Mg} /\left(\mathrm{Mg}+\mathrm{Fe}^{+2}\right)\right]$, calculated with $\mathrm{Fe}^{+3} / \mathrm{Fe}_{T}=$ 0.15 . Symbols denote those samples in the high-REE group $(\Delta)$, the low-REE group $(X)$, and those not analyzed for REE (+). Note that, in general, the groups identified using La abundances also form groups of high and low $\mathrm{TiO}_{2}$ contents. There are, however, more intermediate samples than were identified using the REE.

net is retained in the source in order to fractionate the mid and heavy REE. As shown in Figure 6 (middle), the average melt derived in a fractional melting process (source with REE abundances equal to $2 \times$ chondrites) can match the observed data very well. These models are not unique, and Leeman et al $(1977,1979)$ have illustrated the range of equilibrium melting models that account for the REE content of Hawaiian tholeiites. Alternatively, successful models can be developed with sources relatively depleted in light REE compared with chondrites (Leeman et al., 1979). For Hawaiian tholeiites, such sources are suggested by Nd-isotope data (DePaolo and Wasserburg, 1976; O'Nions et al., 1977). Further, some Hawaiian tholeiites (Koolau: Schilling and Winchester, 1969; but see discussion by Frey, 1979 and Leeman et al., 1979; Lanai: Leeman et al., 1979) and Hawaiian ridge tholeiites (La Perouse Pinnacle: Frey and Clague, unpublished) have chondrite-normalized La less than Ce. Consistent with these data, a small proportion of Hawaiian lherzolites (Frey, 1979) are relatively depleted in light REE, compared with chondrites (e.g., PAL-3 in Figure 6; lower). A source such as PAL-3 could yield the REE abundances in the Suiko (and Hawaiian tholeiites) tholeiites by small degrees of melting (see Figure 6, middle).

Green (1970) concluded that primary tholeiitic basalts from Kilauea formed in equilibrium with olivine and orthopyroxene but not garnet. As demonstrated by Frey et al. (1978, page 494 and figure 9), if Hawaiian tholeiites did not form in equilibrium with residual garnet, the REE abundances in the mantle source must 


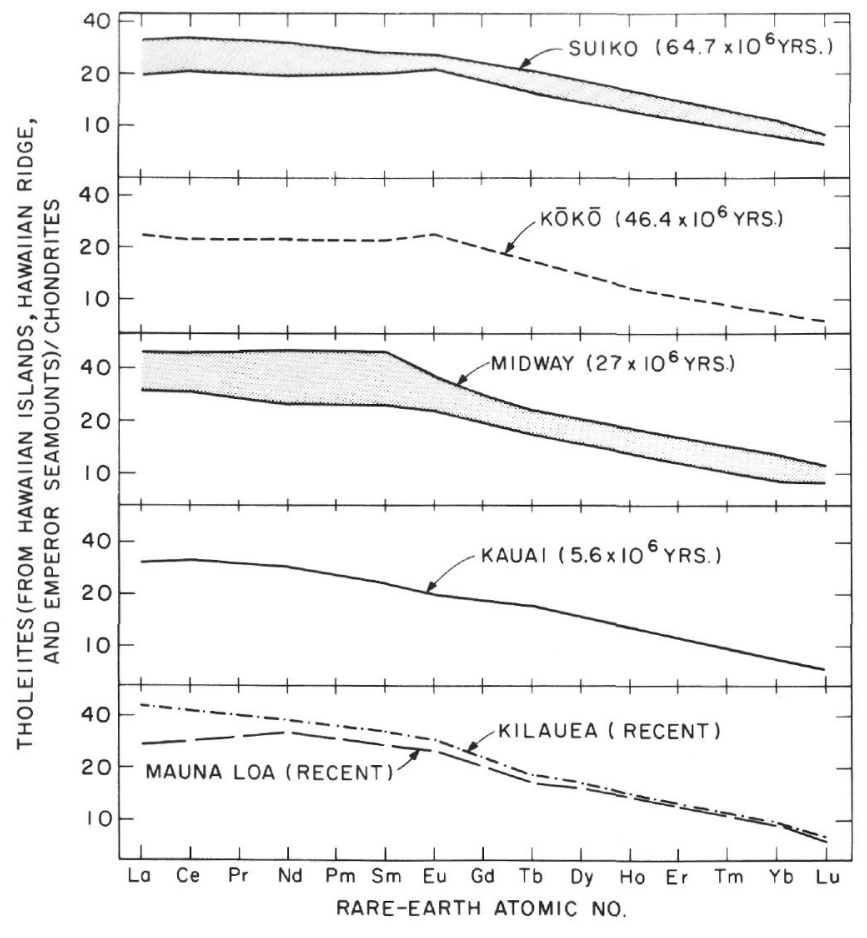

Figure 5. Chondrite-normalized REE abundances in Suiko tholeiites (range for Samples 34-7, 39-5, and 40-2 from high-TiO ${ }_{2}$ group and for Samples 19-5, 42-3, and 42-5 from the low-TiO 2 group), compared with Kōkō Seamount tholeiites, Sample 43-51 (Clague and Dalrymple, 1973; data from Frey and Clague, unpublished), Midway Island tholeiites (three flows from Dalrymple et al., 1977; data from Frey and Clague, unpublished), Kauai tholeiite (74 POH-6, Clague, unpublished), and recent tholeiites from Hawaii (Kilauea, average of 10 and Mauna Loa, average of 12, Leeman et al., 1977, 1979).

have a ratio of light REE to heavy REE similar to that in the Hawaiian tholeiites. Magmas derived from such sources will have REE abundances like the Suiko tholeiites after melting eliminates all residual phases except olivine and orthopyroxene. Therefore, the experimental petrological constraint (Green, 1970) that Hawaiian tholeiites did not form in equilibrium with garnet requires a mantle source with relative abundances of REE similar to that of Suiko tholeiites. Presumably, this relative light-REE enrichment resulted from a recent (relative to the half-life of ${ }^{147} \mathrm{Sm}$ ) "metasomatic" event, as postulated by Frey and Green (1974) and Frey and Prinz (1978).

Suiko tholeiites of the low- $\mathrm{TiO}_{2}-\mathrm{La}$ group with the highest $\mathrm{Mg}$ numbers (58 to 61) have lower REE, especially light-REE, abundances than the more mafic (Mg number 68) members of the high- $\mathrm{TiO}_{2}$-La group (Figure 6, upper). These differences would be accentuated if these low- $\mathrm{TiO}_{2}-\mathrm{La}$ group tholeiites (with relatively low $\mathrm{Mg}$ number) had experienced more extensive fractional crystallization than the mafic members of the high- $\mathrm{TiO}_{2}-\mathrm{La}$ group. Thus, it is likely that there are small but significant differences in source composition

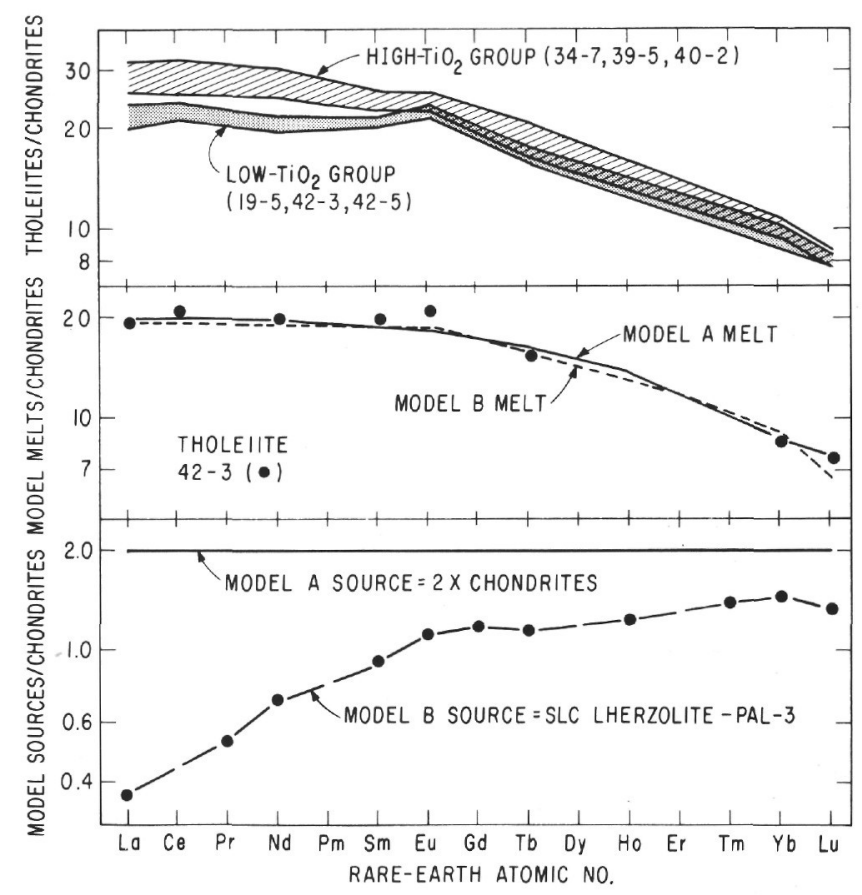

Figure 6. Upper: Range of chondrite-normalized REE abundances for most mafic (highest $\mathrm{Mg}$ number) members of the high-TiO $-\mathrm{La}$ and low-TiO $-\mathrm{La}$ groups. Middle: Solid circles indicate chondrite-normalized data for low-TiO - La tholeiite, Sample 42-3. The solid line, Model $A$ melt, is the average melt for 10 per cent fractional melting of a source with REE abundances equal to $2 \times$ chondrites and an initial mineralogy of 50 per cent olivine, 25 per cent orthopyroxene, 19 per cent clinopyroxene, and 6 per cent garnet. Melt is formed of 5 per cent olivine, 5 per cent orthopyroxene, 45 per cent clinopyroxene, and 45 per cent garnet. Partition coefficients are set number 3 of Frey et al. (1978). The dashed line, Model B melt, is a 1.4 per cent batch melt of a source with $R E E$ abundances equal to Hawaiian lherzolite $P A L-3$ and an initial mineralogy of 50 per cent olivine, 25 per cent orthopyroxene, 22 per cent clinopyroxene, and 3 per cent garnet. Melt proportion and partition coefficients are same as in Model A. Lower: Model A source equal to $2 \times$ chondrites; Model B source equal to chondrite-normalized REE abundances for Salt Lake Crater lherzolite inclusion (PAL-3).

or melting condition (e.g., variation in degree of melting or residual mineralogy) for the two Suiko tholeiite groups. Leeman et al. $(1977,1979)$ reached a similar conclusion for recent Hawaiian tholeiites.

\section{Incompatible Trace Elements: $\mathrm{Sr}, \mathrm{Ba}, \mathrm{Zr}$, Hf, Ta, Th}

There are strong positive correlations between abundances of some incompatible trace elements, such as $\mathrm{Zr}$, $\mathrm{Hf}, \mathrm{Ta}, \mathrm{REE}, \mathrm{P}_{2} \mathrm{O}_{5}$, and $\mathrm{TiO}_{2}$. For example, these Suiko seamount tholeiites have $\mathrm{Ti} / \mathrm{Zr}=98 \pm 5$ (Figure 7 and Table 5). The strong abundance correlations among the light $\mathrm{REE}, \mathrm{Zr}, \mathrm{Hf}, \mathrm{Ta}$, and $\mathrm{P}_{2} \mathrm{O}_{5}$ are indicated in Figure 8 and Table 5 . Thus, the high-La- $-\mathrm{TiO}_{2}$ group 


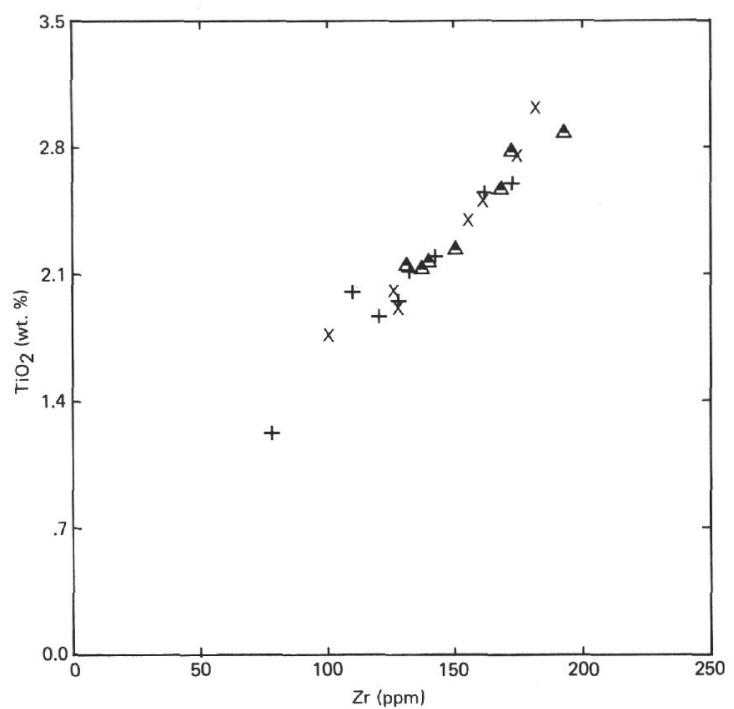

Figure 7. $\mathrm{TiO}_{2}$ content as a function of $\mathrm{Zr}$ abundance for Suiko tholeiites. Symbols as in Figure 4.

TABLE 5

Comparison of Key Average Oxide and Element Abundance Ratios in Suiko Tholeiites, Recent Hawaiian Tholeiites, and Mid-Ocean Ridge Basalts (MORB) and Chondrites

\begin{tabular}{lccccc}
\hline & Suiko & Kilauea & $\begin{array}{c}\text { Mauna } \\
\text { Loa }\end{array}$ & MORB & Chondrites \\
\hline $\mathrm{Al}_{2} \mathrm{O}_{3} / \mathrm{TiO}_{2}$ & $6 \pm 1$ & 5.9 & 6.0 & 22 & 20.4 \\
$\mathrm{CaO} / \mathrm{TiO}_{2}$ & $4.2 \pm 0.8$ & 4.9 & 4.4 & 16.3 & 16.8 \\
$\mathrm{TiO}_{2} / \mathrm{P}_{2} \mathrm{O}_{5}$ & $9.7 \pm 1$ & 10.3 & 10.5 & 11 & 0.5 \\
$\mathrm{Ti} / \mathrm{Zr}$ & $98 \pm 5$ & 76 & 96 & 100 & 110 \\
$\mathrm{Zr} / \mathrm{Hf}$ & $39 \pm 3$ & 53 & 38 & $?$ & 44 \\
$\mathrm{La} / \mathrm{Hf}$ & $2.7 \pm 0.3$ & 3.9 & 2.7 & $\sim 1$ & 1.6 \\
$\mathrm{La} / \mathrm{Yb}$ & $3.8-4.6$ & 7.8 & 4.7 & $<1.65$ & 1.65 \\
$\mathrm{P}_{2} \mathrm{O}_{5} / \mathrm{Ce}$ & $95 \pm 8$ & 72 & 80 & 120 & 2900 \\
\hline
\end{tabular}

Data from Kirkpatrick et al. (this volume), Leeman et al. (1979), Sun and Nesbitt (1977), Wedepohl (1975), Frey et al. (1974).

and low-La- $\mathrm{TiO}_{2}$ group are characterized by differences in abundance of all immobile, incompatible trace elements. These uniform differences may reflect mantle heterogeneity of incompatible trace-element abundances on an absolute basis.

$\mathrm{K}_{2} \mathrm{O}, \mathrm{Ba}, \mathrm{Sr}$, and $\mathrm{Th}$ do not correlate as strongly with each other or with any of the first group of incompatible elements. For example, Figure 8 demonstrates the rather poor correlation of $\mathrm{Ce}$ and $\mathrm{Sr}$. The poor correlations among $\mathrm{K}_{2} \mathrm{O}, \mathrm{Ba}, \mathrm{Sr}$, and $\mathrm{Th}$ abundances probably result from several causes, including element mobility during low-temperature alteration, poor precision of the analytical data (particularly Th), and possibly from real abundance variations created during petrogenesis.

Incompatible trace elements may be used as a quantitative measure of crystal fractionation between assumed or calculated parental magmas and proposed differentiates. Table 6 lists the results of fractionation calculations (Anderson and Greenland, 1969) using tho- leiites with the highest $\mathrm{Mg}$ values as parental magmas and the most fractionated (lowest $\mathrm{Mg}$-value) basalts as differentiates. Two parent-daughter relations are shown: one for the high-La- $\mathrm{TiO}_{2}$ group and one for the low$\mathrm{La}-\mathrm{TiO}_{2}$ group. The calculations assume that the bulk $D^{\text {crystal/liquid }}$ for each element is zero. The most consistent results are obtained from $\mathrm{P}_{2} \mathrm{O}_{5}, \mathrm{Zr}, \mathrm{Hf}, \mathrm{Ta}$, and the light REE; $\mathrm{K}_{2} \mathrm{O}, \mathrm{Ba}$, and Th produce inconsistent results. Elements yielding consistent calculated fractionation percentages are the same elements with strong positive covariation. These results indicate that differentiated basalt Sample 433C-47-5, 92-100 cm represent about 52 per cent residual liquid of a low-La- $\mathrm{TiO}_{2}$ parental magma having the composition of Sample 433C-42-3, 11-20. The poor mass balance for $\mathrm{K}_{2} \mathrm{O}$ is because of the abundant late-stage zeolites found in Section 433C-47-5. Differentiated basalt Sample 433C-29-2, 94-100 cm represents about 66 per cent residual liquid of a high-La$\mathrm{TiO}_{2}$ parental magma having a composition of the average of Samples 433C-39-5, 87-94 cm and 433C-40-2, $88-96 \mathrm{~cm}$. Based on phenocryst mineralogy, the 48 per
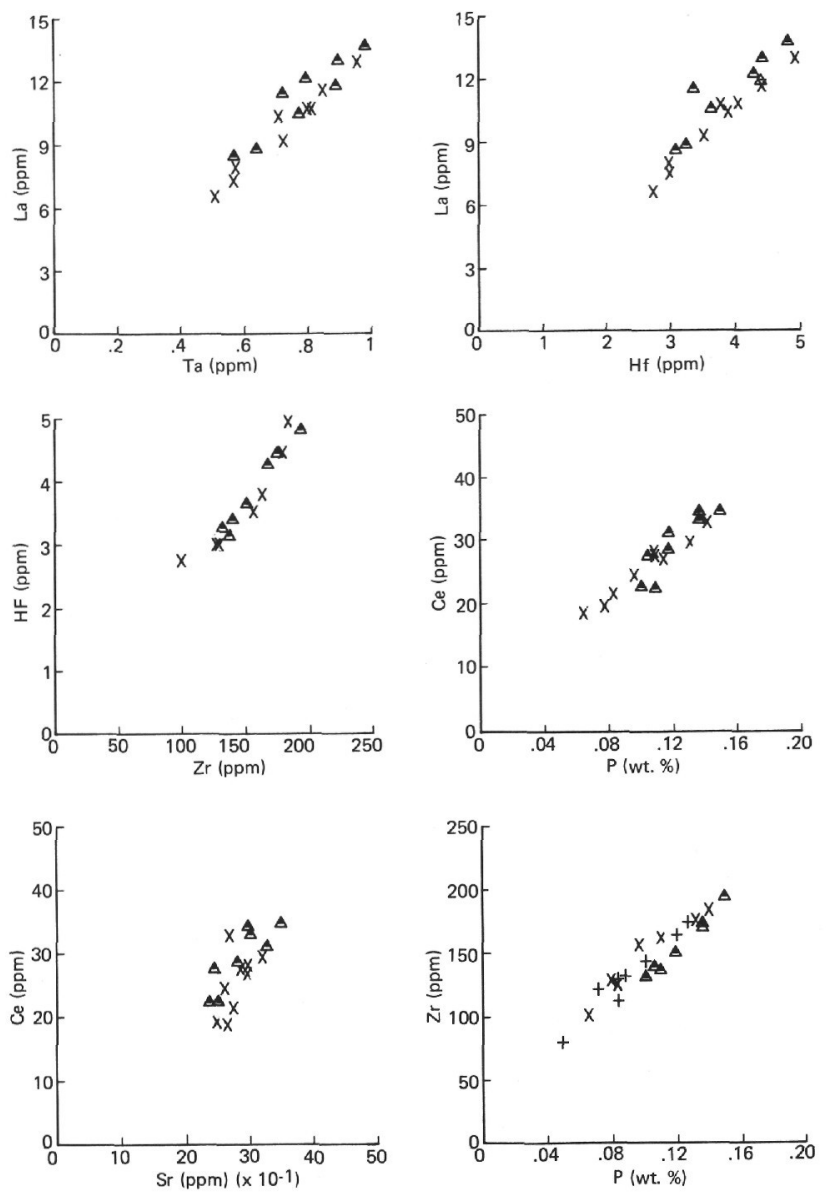

Figure 8. Variation diagrams for incompatible element pairs, La vs. Ta, La vs. Hf, Hf vs. Zr, Ce vs. P, Ce vs. Sr, and $\mathrm{Zr}$ vs. P. All but Ce vs. Sr form strongly correlated trend lines. Symbols as in Figure 4. Note that the low-REE group $(\times)$ has higher $Z r$ relative to $P$ than the high-REE group $(\Delta)$. 
TABLE 6

Models of Shallow Fractionation for Hole 433C Tholeiitic Basalts (all values in ppm, except $\mathrm{P}_{2} \mathrm{O}_{5}$ and $\mathrm{K}_{2} \mathrm{O}$ in wt. \%.)

\begin{tabular}{|c|c|c|c|}
\hline & $\begin{array}{c}\text { Parental Magma, } \\
\text { Sample } \\
42-3,11-20 \mathrm{~cm}\end{array}$ & $\begin{array}{c}\text { Differentiate, } \\
\text { Sample } \\
47-5,92-100 \mathrm{~cm}\end{array}$ & $\begin{array}{c}\text { Calculated \% } \\
\text { Residual Liquid }\end{array}$ \\
\hline $\mathrm{P}_{2} \mathrm{O}_{5}$ & 0.16 & $0.34 \%$ & 47.1 \\
\hline $\mathrm{K}_{2} \mathrm{O}$ & 0.24 & $1.60 \%$ & 15.0 \\
\hline $\mathrm{Ba}$ & 63 & 118 & 53.4 \\
\hline $\mathrm{Zr}$ & 101 & 183 & 55.2 \\
\hline $\mathrm{Hf}$ & 2.7 & 4.9 & 55.1 \\
\hline Ta & 0.51 & 0.96 & 53.1 \\
\hline $\mathrm{Th}$ & 0.5 & 1.1 & 45.5 \\
\hline $\mathrm{La}$ & 6.45 & 12.8 & 50.4 \\
\hline \multirow[t]{6}{*}{$\mathrm{Ce}$} & 18.5 & 32.6 & 56.7 \\
\hline & & & avg. a $52 \pm 4$ \\
\hline & Avg. of Samples & & \\
\hline & $40-2,88-96 \mathrm{~cm}$ & & \\
\hline & and $39-5$, & Sample & \\
\hline & $87-94 \mathrm{~cm}$ & $29-2,94-100 \mathrm{~cm}$ & \\
\hline $\mathrm{P}_{2} \mathrm{O}_{5}$ & 0.25 & $0.35 \%$ & 71.4 \\
\hline $\mathrm{K}_{2} \mathrm{O}$ & 0.22 & $0.95 \%$ & 23.2 \\
\hline $\mathrm{Ba}$ & 99 & 98 & - \\
\hline $\mathrm{Zr}$ & 134 & 194 & 69.1 \\
\hline Hf & 3.75 & 4.8 & 67.7 \\
\hline Ta & 0.6 & 0.99 & 60.6 \\
\hline Th & 0.8 & 0.9 & 88.9 \\
\hline $\mathrm{La}$ & 8.60 & 13.6 & 63.2 \\
\hline \multirow[t]{2}{*}{$\mathrm{Ce}$} & 22.2 & 34.4 & 64.5 \\
\hline & & & avg. ${ }^{\text {a }} 66 \pm 4$ \\
\hline
\end{tabular}

${ }^{\mathrm{a}} \mathrm{K}_{2} \mathrm{O}$ not included in averages.

cent and 34 per cent crystals removed during fractionation are dominated by olivine in the early stages and plagioclase and clinopyroxene in the later stages.

\section{Compatible Trace Elements}

$\mathrm{Ni}, \mathrm{Co}$, and $\mathrm{Cr}$ abundances decrease rapidly with decreasing $\mathrm{Mg}$ number, as expected if olivine (with a trace of chrome spinel) is a major fractionating mineral. Figure 9 shows Ni plotted as a function of $\mathrm{MgO}$ for all the shipboard and shore-based analyses. Leeman and Scheidegger (1977) have shown an apparent inverse correlation of $D_{\mathrm{Ni}}^{\text {ol } / \text { liq }}$ with temperature; Hart and Davis (1978) concluded, however, that this correlation is caused by changes in melt composition with temperature and that $D_{\mathrm{Ni}}^{\text {ol/liq }}$ increases with decreasing $\mathrm{MgO}$ concentration. For the range of basalt compositions in this study, the Hart and Davis (1978) data indicate that $D_{\mathrm{Ni}}^{\text {ol/liq }}$ ranges from about 3 at $\mathrm{MgO}=30$ per cent to 22 at $\mathrm{MgO}=6$ per cent. The linear correlation of $\mathrm{MgO}$ and Ni (Figure 9) indicates that accumulation of olivine is required to account for the high $\mathrm{Ni}$ and $\mathrm{MgO}$ contents in the picritic basalts.

Co abundances show considerable scatter relative to $\mathrm{Mg}$ number, but the trend of decreasing Co content with decreasing $\mathrm{MgO}$ content is clear (Table 2). This trend is consistent with fractionation of olivine, although the $D_{\mathrm{Co}}^{\mathrm{ol} / \mathrm{liq}}$ decreases with temperature (Leeman et al., 1977) which may reflect compositional dependence on temperature (Hart and Davis, 1978). If the temperature

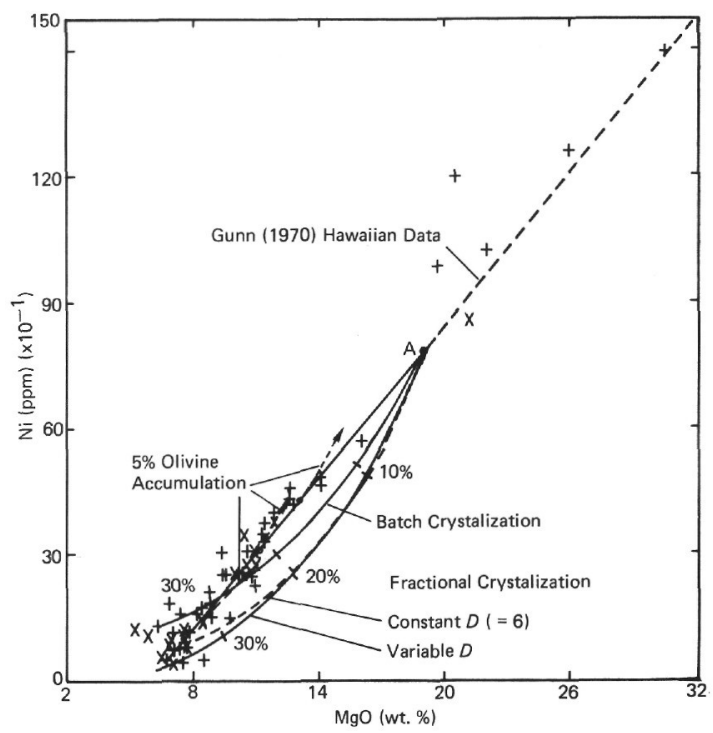

Figure 9. $\mathrm{Ni}$ as a function of $\mathrm{MgO}$ for shore-based analyses (+) (Table 2) and the shipboard analyses $(\times)$. The line is not a best fit to the data, but is the best fit to data from Kilauea basalts (Gunn, 1971) as shown by Hart and Davis (1978). The olivine accumulation and fractional crystallization curves for variable $\mathrm{D}_{N i}^{\text {olliq }}$ are shown as calculated by Hart and Davis (1978). The data from Suiko Seamount are compatible with an olivine accumulation model.

dependence of $D_{\mathrm{Co}}^{\mathrm{ol} / \mathrm{liq}}$ is reinterpreted as a compositional dependence, the $D_{\mathrm{Co}}^{\text {ol/liq }}$ for basaltic magmas having 6 to 11 per cent $\mathrm{MgO}$ is probably on the order of 3 to 5. This implies that Co abundances should not decrease with decreasing $\mathrm{MgO}$ nearly as rapidly as $\mathrm{Ni}$, which has an average $D_{\mathrm{Ni}}^{\text {ol/liq }}$ of about 15 for the compositional range considered. The much smaller variation in Co content (factor of 1.3) in the tholeiites with about 6 to 11 per cent $\mathrm{MgO}$, compared with $\mathrm{Ni}$ abundance variation (factor of 7.2), is consistent with this prediction.

Chromium abundance decreases with decreasing $\mathrm{MgO}$ content, as expected if the fractionating olivine contains a trace amount of chromite. Examination in reflected light shows that all olivine accumulative samples contain chrome spinel with high abundances of $\mathrm{Cr}_{2} \mathrm{O}_{3}$ (see Clague et al., this volume, for representative microprobe analyses of the chrome spinels in these basalts). In contrast to $\mathrm{Ni}, \mathrm{Co}$, and $\mathrm{Cr}, \mathrm{Sc}$ abundances tend to increase with decreasing $\mathrm{Mg}$ number (Figure 10), as expected for olivine fractionation (Gunn, 1971; Leeman and Scheidegger, 1977).

Zinc abundances are rather constant at about 110 to $120 \mathrm{ppm}$; Zn contents weakly tend to increase with increasing abundances of incompatible trace elements. Clague and Beeson (1979) showed that the bulk $D_{\mathrm{Zn}}^{\mathrm{s} / \ell}$ for olivine, clinopyroxene, and plagioclase fractionation is slightly less than unity for a series of fractionated basalts from Molokai. The uniform concentration of $\mathrm{Zn}$ in the Suiko Seamount tholeiitic basalts suggests that the $D_{\mathrm{Zn}}^{\text {ol/liq }}$ is near unity, and this result agrees with a value of 0.95 determined by Gunn (1971) for the 1959 Kilauea Iki basalts. 


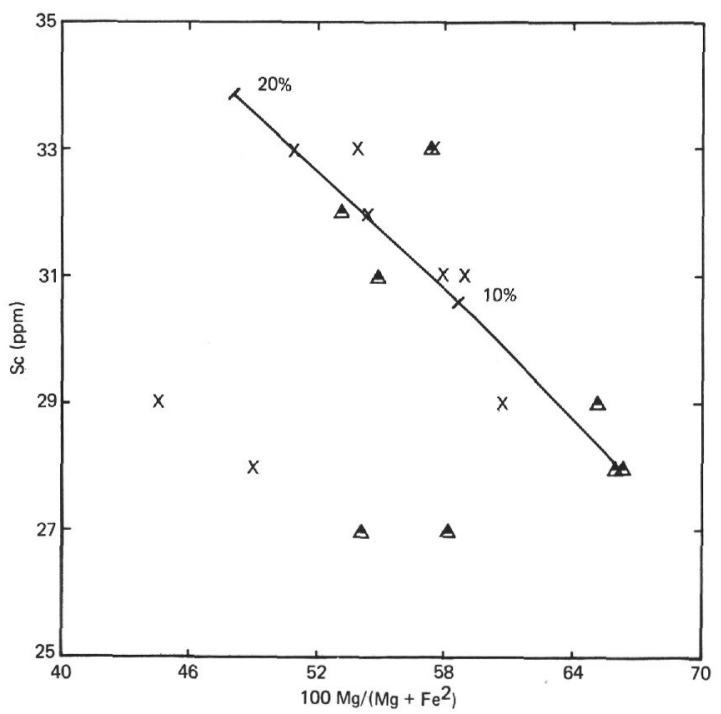

Figure 10. Sc as a function of $100 \mathrm{Mg} /\left(\mathrm{Mg}+\mathrm{Fe}^{+2}\right)$, calculated with $\mathrm{Fe}^{+3} / \mathrm{Fe}_{T}=0.15$. Note the general trend of increasing $\mathrm{Sc}$ with decreasing $\mathrm{Mg}$ value. The high- $(\Delta)$ and low- $(\times)$ REE-group basalts are designated, but there is no apparent correlation of REE group and Sc concentration. The solid line indicates the trend of Sc-enrichment for 0 to 20 per cent batch crystallization of olivine from tholeiite Sample 40-2. $\mathrm{D}_{S c}^{\text {olle }}$ 0.15 (Leeman and Scheidegger, 1977).

The two compositional groups defined on the basis of $\mathrm{La}$ and $\mathrm{TiO}_{2}$ concentrations are not distinguishable on the basis of compatible trace-element abundances. This result implies a similar source concentration of compatible trace elements and similar residue mineralogy for the two compositional groups.

\section{Comparison of Suiko and Hawaiian Tholeiites}

The ratios of moderately incompatible element abundances in Suiko tholeiites are similar to those in Hawaiian tholeiites. For example, the $\mathrm{P}_{2} \mathrm{O}_{5} / \mathrm{Zr}$ ratios of Suiko tholeiites overlap with those of Hawaiian tholeiitic and alkalic basalts, but are distinct from that of the posterosional basalts (Clague and Frey, unpublished data).

Further, the distinctive features (little light-REE fractionation with more extensive mid- and heavy-REE fractionation) of the chondrite-normalized REE patterns of the Suiko tholeiites are similar to the REE patterns of modern Hawaiian tholeiites (e.g., Kilauea, Mauna Loa, and Kauai), Hawaiian Ridge tholeiites (e.g., Midway Island), and younger Emperor seamounts such as Kōkō (Figure 5). We agree with Leeman et al. $(1977,1979)$ that in detail there are important differences in trace-element abundances between Hawaiian volcanoes (e.g., Kilauea and Mauna Loa) that imply differences in mantle-source composition and/or residual mineralogy. At this stage in our understanding of Hawaiian-Emperor volcanism, however the gross similarity in REE distributions is most striking. In addition, these REE distributions are distinct from those in tholeiites from other proposed "hot spot" regions. For exam- ple, tholeiitic basalts from Iceland, Galapagos (Pinzon Island), and the northwest U. S. have lower $\mathrm{La} / \mathrm{Yb}$ ratios, reflecting higher heavy-REE abundances (Figure 11). Also, most of these tholeiites have more extensive relative fractionation of light REE (cf. Figures 5 and 11) than Hawaiian tholeiites.

As a group, Hawaiian tholeiites, including Suiko tholeiites, have very low $\mathrm{Al}_{2} \mathrm{O}_{3} / \mathrm{TiO}_{2}$ and $\mathrm{CaO} / \mathrm{TiO}_{2}$ ratios (Table 5), compared with chondrites and primitive mid-ocean ridge tholeiites (MORB). These differences probably reflect crystal fractionation, but in part, these low ratios may also result from the unusually high $\mathrm{TiO}_{2}$ contents of Hawaiian tholeiites and their inferred mantle source; e.g., Hubbard (1969) noted the high $\mathrm{TiO}_{2}$ contents of Hawaiian tholeiites relative to MORB of similar $\mathrm{Mg}$ number, and Frey et al. (1978, page 478) commented on the high $\mathrm{TiO}_{2}$ content of Hawaiian tholeiites relative to southeastern Australian tholeiites.

However, $\mathrm{Ti} / \mathrm{Zr}$ and $\mathrm{TiO}_{2} / \mathrm{P}_{2} \mathrm{O}_{5}$ ratios are very similar in Suiko, Hawaiian, and ocean ridge tholeiites (Table 5), whereas other ratios, such as $\mathrm{La} / \mathrm{Yb}, \mathrm{La} / \mathrm{Hf}$ and $\mathrm{P}_{2} \mathrm{O}_{5} / \mathrm{Ce}$, clearly distinguish MORB from Hawaiian and Emperor tholeiites (Table 5). Consistent with the slight differences in REE abundances of Suiko, Kilauea, and Mauna Loa tholeiites (Figure 6), the ratios of incompatible trace elements in Suiko tholeiites are intermediate between ratios for modern Hawaiian tholeiites from Kilauea and Mauna Loa (Table 5).

We conclude that the trace-element abundance features of Suiko tholeiites are similar to younger tholeiites formed along the Emperor and Hawaiian ridges and on the modern Hawaiian Islands. Therefore, the data require an overall similarity in the source composition and the petrogenesis of tholeiites erupted along the Hawaiian hot-spot trace; furthermore, there is no evidence for

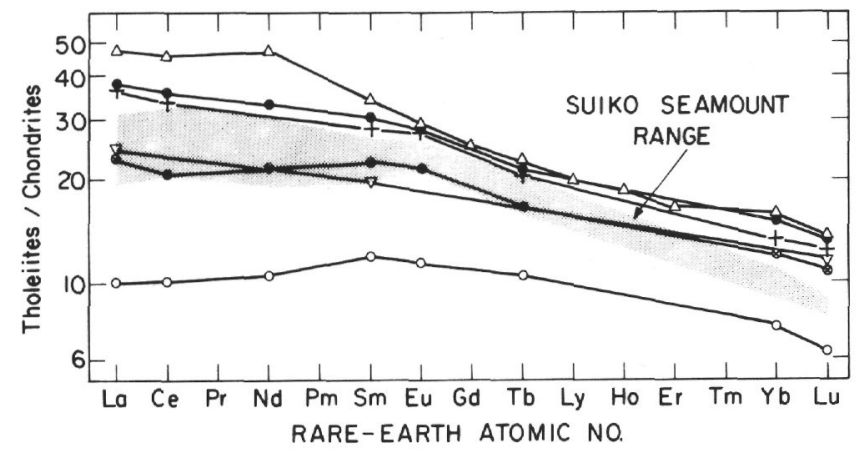

Figure 11. Chondrite-normalized REE abundances for tholeiites from other postulated hot-spot areas. Least differentiated neovolcanic Icelandic tholeiites (•, Skagi, IC-122; O, Langjokull, HS 605; $\otimes$, Reykjanes Peninsula, IC-55) from Schilling et al. (1978). Galapagos tholeitte (+, DH-8K, from Pinzon, Island) from Lindstrom (1976). Steens Mountain, Oregon $(\Delta$, group $E$ average from Helmke and Haskin, 1973). Picture Gorge type of Columbia River $(\nabla$, average of high-Mg-type from Nathan and Fruchter, 1974). The strippled area indicates the range for 17 Suiko tholeiites (this paper). 
systematic geochemical differences with time. The unique trace-element features of Hawaiian tholeiites, compared with MORB, can be explained by differences in source composition (e.g., higher $\mathrm{La} / \mathrm{Yb}, \mathrm{La} / \mathrm{Hf}$, and $\mathrm{Ce} / \mathrm{P}_{2} \mathrm{O}_{5}$ in the Hawaiian source mantle), but some geochemical differences between "hot-spot" tholeiites may reflect systematic differences in the melting process (e.g., residual garnet in the Hawaiian mantle but not in the Icelandic mantle).

During the approximately $64 \mathrm{~m} . \mathrm{y}$. of Emperor-Hawaiian volcanism, about $10^{6} \mathrm{~km}^{3}$ of tholeiitic basalt with similar geochemical characteristics was erupted to form about 90 separate volcanoes. The larger volcanoes are composed of about $2 \times 10^{4} \mathrm{~km}^{3}$ of basalt and, using a conservative estimate of 20 per cent partial melting of the mantle source region (Ringwood, 1975), requires $10^{5}$ $\mathrm{km}^{3}$ of source region for a single volcano. There are three possible source areas that underlie the volcanoes: (1) the lithospheric plate, (2) the shallow asthenosphere, and (3) the lower mantle.

Present mantle convection models (McKenzie, 1979, Richter and Ribe, 1979) do not allow for preservation over long time periods of a large-scale geochemical anomaly in the asthenosphere such as that required to generate the Hawaiian-Emperor volcanism. The lower lithosphere is a possible source region, although the volume problem remains critical, as only lithosphere geochemically distinct from that accreted near mid-ocean ridges could be a possible source region for the Hawaiian-Emperor volcanism. This constraint limits the potential source region to the lower lithosphere, at best, or could eliminate the lithosphere as a source region, at worst. If the lower lithosphere is a geochemically appropriate source region, the volume of basalt generated would require partial melting of a $50-\mathrm{km}$-diameter cylinder $50 \mathrm{~km}$ tall underlying each volcano. This is a severe constraint, since it requires partial melting of nearly the entire lower lithosphere underlying the chain. Detrick and Crough (1978) presented convincing arguments in favor of hot spots being caused by thermal anomalies. Their model of the heating, thinning, and uplift of the lithosphere above hot spots suggests that the magmas that form the volcanoes could result from partial melting of the lower lithosphere by heating and decompression.

The final possible source region is the lower mantle, which remains a convenient and plausible source for the observed volcanism.

\section{CONCLUSIONS}

1) All flows from flow Unit 4 to the bottom of Hole 433C are tholeiitic basalts partially altered by lowtemperature processes.

2) These tholeiites can be subdivided into two groups on the basis of $\mathrm{TiO}_{2}$ and incompatible-element contents.

3) Shallow crystal fractionation has modified most samples, and the most differentiated basalts may represent as little as $\mathbf{4 8}$ per cent residual liquid.

4) The least fractionated tholeiitic basalts from Suiko seamount have chondrite-normalized REE patterns with uniform relative light-REE enrichment (La to
$\mathrm{Eu}=20$ to $30 \times$ chondrites) and relatively lower but fractionated abundances of mid and heavy REE (Tb to $\mathrm{Lu}=20$ to $8 \times$ chondrites).

5) Comparison of Hole $433 \mathrm{C}$ tholeiitic basalts with modern Hawaiian tholeiitic basalts shows that the distinctive REE pattern is typical of tholeiites from the Emperor Seamounts, Hawaiian Ridge and Hawaiian Islands.

6) The mantle source region for the tholeiitic basalts making up the vast bulk of the Hawaiian-Emperor chain has not changed dramatically during 64 m.y. of eruption generating $10^{6} \mathrm{~km}^{3}$ of basalt. We suggest that these basalts are generated from within the lower portion of the lithospheric plate or in the lower mantle.

\section{ACKNOWLEDGMENTS}

The nuclear irradiations were conducted at the MIT nuclear reactor, and the X-ray analyses were done at the U. S. Geological Survey at Menlo Park, CA. We thank S. Roy and M. Roden for technical assistance during data acquisition and $\mathrm{L}$. F. Espos for the X-ray analytical data. This research was partially supported by National Science Foundation, Earth Science Section Grant DES-75-02900 and Oceanography Section Grant OCE-76-82515.

\section{REFERENCES}

Anderson, A. T. and Greenland, L. P., 1969. Phosphorus fractionation diagram as a quantitative indicator of crystallization differentiation of basaltic liquids, Geochem. Cosmochem. Acta, v. 33, pp. 493-505.

Clague, D. A. and Beeson, M. H., in press. Trace element geochemistry of the East Molokai Volcanic Series, Hawaii, submitted to Am. Jour. Sci. (Jackson volume).

Clague, D. A. and Dalrymple, G. B., 1973. Age of Kōkō Seamount, Emperor Seamount chain, Earth Planet. Sci. Lett., v. 17, pp. $411-415$.

Dalrymple, G. B., Clague, D. A., and Lanphere, M. A., 1977. Revised age for Midway Volcano, Hawaiian Volcanic Chain, Earth Planet. Sci. Lett., v. 37, pp. 107-116.

DePaolo, D. J. and Wasserburg, G., 1976. Inferences about magma sources and mantle structure from variations of ${ }^{143} \mathrm{Nd} / 144 \mathrm{Nd}$, Geophys. Res. Lett., v. 3, pp. 743-746.

Detrick, R. S. and Crough, S. T., 1978. Island subsidence, hot spots, and lithospheric thinning, Jour. Geophys. Res., v. 83 , pp. 1236-1244.

Frey, F. A., in press. The origin of pyroxenites and garnet pyroxenites from Salt Lake Crater, Oahu, Hawaii: Trace element evidence, Am. Jour. Sci. (Jackson volume).

Frey, F. A., Bryan, W. B., and Thompson, G., 1974. Atlantic Ocean Floor: Geochemistry and petrology of basalts from Legs 2 and 3 of the Deep Sea Drilling Project, J. Geophys. Res., v. 79, pp. 5507-5527.

Frey, F. A. and Green, D. H., 1974. The mineralogy, geochemistry and origin of lherzolite inclusions in Victorian basanites, Geochem. Cosmochem. Acta, v. 38, pp. 1023-1059.

Frey, F. A., Green, D. H., and Roy, S. D., 1978. Integrated models of basalt petrogenesis: A study of quartz tholeiites to olivine melilitites from South Eastern Australia utilizing geochemical and experimental petrologic data, Jour. Petrol., v. 19, pp. 463-513.

Frey, F. A. and Prinz, M., 1978. Ultramafic inclusions from San Carlos, Arizona: Petrologic and geochemical data bearing on their petrogenesis, Earth Planet. Sci. Lett., v. 38 , pp. 129-176. 
Green, D. H., 1970. A review of experimental evidence on the origin of basaltic and nephelinitic magmas, Phys. Earth Planet. Int., v. 3, pp. 221-235.

Gunn, B. M., 1971. Trace element partition during olivine fractionation of Hawaiian basalts, Chem. Geology, v. 8, pp. 1-13.

Hart, S. R. and Davis, K. E., 1978. Nickel partitioning between olivine and silicate melt, Earth Planet. Sci. Lett., v. 40, pp. 203-219.

Helmke, P. A. and Haskin, L. A., 1973. Rare-earth elements, $\mathrm{Co}, \mathrm{Sc}$, and $\mathrm{Hf}$ in the Steens Mountain basalts, Geochim. Cosmochim. Acta., v. 37, pp. 1513-1529.

Hubbard, N. J., 1969. A chemical comparison of oceanic ridge, Hawaiian tholeiitic and Hawaiian alkalic basalts, Earth Planet. Sci. Lett., v. 5, pp. 346-352.

Jackson, E. D., Silver, E. A., and Dalrymple, G. B., 1972. Hawaiian-Emperor chain and its relation to Cenozoic circum-Pacific tectonics, Geol. Soc. Am. Bull., v. 83, pp. 601-618.

King, B. S., Espos, L. F. and Fabbi, B. P., 1978. X-ray fluorescence: minor and trace element analysis of silicate rocks in the presence of large interelement effects. In Barrett, C. A., Leyden, D. E., Newkirk, J. D., and Ruud, C. O., (Eds.), Advances in X-Ray Analysis, v. 21: (Plenum Pub. Co.)

Kuno, H. and Aoki, A., 1970. Chemistry of ultramafic nodules and their bearing on the origin of basaltic magmas, Physics Earth and Planetary Interiors, v. 3, pp. 273-301.

Leeman, W. P., Budahn, J. R., Gerlach, D. C., Smith, D. R. and Powell, B. N., in press. Origin of Hawaiian tholeiites: trace element constraints, Amer. J. Sci.

Leeman, W. P., Murali, A. V., Ma, M.-S., and Schmitt, R. A., 1977. Mineral constitution of the mantle source region for Hawaiian basalts-Rare earth element evidence for mantle heterogeneity. In Magma Genesis, Bull. 96 of the State of Oregon, Dept. of Geology and Mineral Industries, Portland, Oregon, pp. 169-183.

Leeman, W. P. and Scheidegger, K. F., 1977. Olivine/liquid distribution coefficients and a test for crystal-liquid equilibrium, Earth Planet Sci. Lett., v. 35, pp. 247-257.

Lindstrom, M., 1976. Geochemical studies of volcanic rocks from Pinzon and Santiago Islands, Galapagos Archipelago, Ph.D. thesis, Univ. of Oregon, Eugene.

Macdonald, G. A., 1968. Composition and origin of Hawaiian lavas, Geol. Soc. Am. Memoir 116, pp. 477-522.
Macdonald, G. A. and Katsura, T., 1964. Chemical composition of Hawaiian lavas, Jour. Petrology, v. 6, pp. 82-133.

McKenzie, D., in press. Finite deformation during fluid flow, Geophys. Jour. Roy. Astron. Soc. London.

Morgan, W. J., 1971. Convection plumes in the lower mantle, Nature, v. 30 , pp. 42-43.

Nathan, S. and Fruchter, J. S., 1974. Geochemical and paleomagnetic stratigraphy of the Picture Gorge and Yakima basalts (Columbia River Group) in Central Oregon, Geol. Soc. Amer. Bull., v. 85, pp. 63-76.

O'Nions, R. K., Hamilton, P. J., and Evensen, N. M., 1977. Variations in ${ }^{143} \mathrm{Nd} /{ }^{144} \mathrm{Nd}$ and ${ }^{87} \mathrm{Sr} /{ }^{86} \mathrm{Sr}$ in oceanic basalts, Earth Planet. Sci. Lett., v. 34, pp. 13-22.

Reid, J. B. and Woods, G. A., in press. Oceanic mantle beneath the southern Rio Grande rift, Earth Planet. Sci. Lett.

Richter, F.M. and Ribe, N. M., in press. On the importance of advection in determining the local isotopic composition of the mantle, Earth Planet. Sci. Lett.

Ringwood, A. E., 1975. Composition and Petrology of the Earth's Mantle. New York (McGraw-Hill), 618 pp.

Schilling, J.-G., Sigurdsson, H., and Kingsley, R. H., 1978. Skagi and western neovolcanic zones in Iceland: 2 . Geochemical variation, J. Geophys. Res., v. 83, pp. 3983-4002.

Schilling, J.-G., and Winchester, J. W., 1969. Rare earth contribution to the origin of Hawaiian lavas, Contr. Mineral. and Petrol., v. 23, pp. 27-37.

Shaw, H. R. and Jackson, E. D., 1973. Linear island chains in the Pacific: Result of thermal plumes or gravitational anchors? Jour. Geophys. Res., v. 78, pp. 8634-8652.

Stearns, H. T., 1946. Geology of the Hawaiian Islands, $\mathrm{Ha}$ waii Hydrography Div. Bull. 8, 112 pp.

Sun, S. S. and Hanson, G. N., 1975. Origin of Ross Island basanitoids and limitations upon the heterogeneity of mantle sources for alkali basalts and nephelinites, Cont. Mineral. and Petrol., v. 52, pp. 77-106.

Sun, S. S. and Nesbitt, R. W., 1977. Chemical heterogeneity of the Archean mantle, composition of the earth and mantle evolution, Earth Planet. Sci. Lett., v. 35, pp. 429-448.

Wedepohl, K. H., 1975. The contribution of chemical data to assumptions about the origin of magmas from the mantle, Fortschr. Miher., v. 52, pp. 141-172. 